\title{
Anti-proliferative and apoptosis-inducible activity of Sarcodonin G from Sarcodon scabrosus in HeLa cells
}

\author{
MEI DONG ${ }^{1,2^{*}}$, SHI-PING CHEN ${ }^{2 *}$, KAZUKO KITA $^{2 *}$, YOSHINOBU ICHIMURA $^{2}$, WEN-ZHI GUO ${ }^{2}$, \\ SA LU $^{2}$, SHIGERU SUGAYA ${ }^{2}$, TAKAKI HIWASA ${ }^{3}$, MASAKI TAKIGUCHI $^{3}$, NAOMI MORI $^{4}$, \\ ATSUSHI KASHIMA ${ }^{4}$, KEIJI MORIMURA $^{4}$, MITSURU HIROTA $^{4 *}$ and NOBUO SUZUKI ${ }^{2 *}$ \\ ${ }^{1}$ Department of Medicinal Natural Product Chemistry, School of Pharmaceutical Sciences, Hebei Medical University, \\ Shijiazhuang 050017, P.R. China; Departments of ${ }^{2}$ Environmental Biochemistry, ${ }^{3}$ Biochemistry and Genetics, \\ Graduate School of Medicine, Chiba University, Inohana 1-8-1, Chuo-ku, Chiba 260-8670; ${ }^{4}$ Department of Bioscience \\ and Biotechnology, Faculty of Agriculture, Shinshu University, 8304 Minami-minowa, Kami-ina, Nagano, Japan
}

Received July 29, 2008; Accepted September 29, 2008

DOI: 10.3892/ijo_00000142

\begin{abstract}
There is an ongoing search for plant-derived diterpenes, especially for diterpenes with anti-inflammatory activity that also have anti-proliferative effects on human cancer cells. A cyathane-type diterpene, Sarcodonin G (SG), isolated from the mushroom Sarcodon scabrosus and already reported to have anti-inflammatory activity, inhibited proliferation of HeLa cells to the greatest extent among 4 cyathane diterpenes tested. SG showed an $\mathrm{IC}_{50}$ (50\% inhibition concentration) of $20 \mu \mathrm{M}$, estimated by MTT assay 2 days after culture of cells with the chemical. SG treatment of HeLa cells resulted in dose-dependent generation of apoptotic events such as DNA-laddering $(\leq 100 \mu \mathrm{M})$. Moreover, SG-treated HeLa cells showed activation of caspase- 3 and caspase- 9 and increase of $\mathrm{Bax} / \mathrm{Bcl}-2$ ratios, as analyzed by Western blot analysis. The anti-proliferative effects of SG treatment on HeLa cells were lessened by a caspase inhibitor, Z-VAD-FMK. SG also showed anti-proliferative effects toward 5 other human cancer cell lines with $\mathrm{IC}_{50}$ values of $20-40 \mu \mathrm{M}$. Because of these anti-proliferative effects via possible caspase activation, SG holds promise of being a novel anti-proliferative agent deserving further investigation.
\end{abstract}

Correspondence to: Dr Nobuo Suzuki, Department of Environmental Biochemistry, Graduate School of Medicine, Chiba University, Inohana 1-8-1, Chuo-ku, Chiba 260-8670, Japan

E-mail:nobuo@faculty.chiba-u.jp

Dr Mitsuru Hirota, Department of Bioscience and Biotechnology, Faculty of Agriculture, Shinshu University, 8304 Minami-minowa, Kami-ina, Nagano, Japan

E-mail: hirotam@shinshu-u.ac.jp

${ }^{*}$ Contributed equally

Key words: cyathane-type diterpene, Sarcodonin G, human cancer cells, anti-proliferative effect, apoptosis

\section{Introduction}

Plants are thought to contain chemical compounds that inhibit proliferation of cancer-derived cells in vitro, and many attempts have been made to isolate anti-cancer drugs from plants. For example, the diterpene paclitaxel $\left(\operatorname{Taxol}^{\circledR}\right)$ is a well-known anti-proliferative agent isolated from Taxus brevifolia $(1,2)$. Various groups conducted research on other diterpene species with the aim of finding more effective agents for the treatment of cancer (3).

Instead of searching for anti-proliferative compounds from plants in the first place, it would be possible to investigate known anti-inflammatory compounds as possible inhibitors of cell proliferation and tumor promotion activity $(4,5)$. We recently found that $\mathrm{SG}$, one of the diterpenes of the cyathane type that has a tricyclic carbon skeleton, suppressed inflammation induced by a tumor promoter, 12-O-tetradecanoylphorbol-13-acetate (TPA) $(4,6)$. SG was first isolated from the mushroom Sarcodon scabrosus by Shibata et al and synthesized by Edward et al $(7,8)$. There have been only a few reports that diterpenes from mushrooms have anti-proliferative activity on cancer-derived cells and therefore could be an anti-cancer drug (9). It is of great interest to us whether SG has the ability to inhibit cell proliferation of cancer-derived cells.

There are cytotoxic drugs that act primarily by inducing apoptosis in sensitive target cells (10). Preliminarily data suggests apoptosis occurs in SG-treated HeLa cells, as determined by transmission electron microscopy showing chromatin condensation, marginal convergency and fragmentation (11). In the present study, we first compared the antiproliferative effect of SG with that of other 3 cyathane diterpenes from Sarcodon scabrosus in HeLa cells. We further confirmed that the anti-proliferative effect of SG was actually induced via the apoptotic signaling pathway and elucidated the molecular mechanisms of SG-induced apoptotic events. We also examined whether SG inhibits cell proliferation of 5 other cancer cell lines in addition to HeLa cells. 


\section{Materials and methods}

Agents. Cyathane diterpenes tested were isolated from the fruiting body of Sarcodon scabrosus. Dry fruiting bodies of S. scabrosus $(1.3 \mathrm{~kg}$ ) were extracted with methylene chloride and the extract was subjected to silica gel chromtography with ethyl acetate/hexane mixtures by $10 \%$ stepwise elution to give 20,50,60 and 70\% ethyl acetate eluates.

The $20 \%$ ethyl acetate/hexane eluate was further purified with ODS column chromatography with $90 \%$ methanol/ water to give sarcodonin E (19-O-acetyl-sarcodonin A, 60 mg) $(7,12)$. Sarcodonin E: $[\alpha]_{\mathrm{D}}^{22}+705^{\circ}$ (c $\left.0.79, \mathrm{CHCl}_{3}\right)$; HREIMS: $m / z$ 358.2144 (calculated for $\mathrm{C}_{22} \mathrm{H}_{30} \mathrm{O}_{4}, 358.2123$ ); EIMS $m / z$ (relative intensity): 358[M] $]^{+}$(69), 298 (25), 280 (65), 265 (88), 199 (74), 59 (100); IR (film) $v_{\max } \mathrm{cm}^{-1}: 3480(\mathrm{OH})$, 2936, 2861, 1739 (C=O), 1671 (CHO), 1574, 1167; ' ${ }^{1} \mathrm{H}-\mathrm{NMR}$ $\left(500.1 \mathrm{MHz}, \mathrm{CDCl}_{3}\right) \delta_{\mathrm{H}}: 9.47(\mathrm{~s}, 1 \mathrm{H}), 6.84(\mathrm{dd}, J=8.0 \mathrm{~Hz}$, $2.5 \mathrm{~Hz}, 1 \mathrm{H}), 6.11(\mathrm{~d}, J=7.5 \mathrm{~Hz}, 1 \mathrm{H}), 4.16(\mathrm{dd}, J=10.5,8.0 \mathrm{~Hz}$, 1H), $3.92(\mathrm{dd}, J=10.5,7.3 \mathrm{~Hz}, 1 \mathrm{H}), 3.74(\mathrm{~d}, J=5.0 \mathrm{~Hz}, \mathrm{I}$ H), $3.17(\mathrm{dd}, J=18.3 \mathrm{~Hz}, 1 \mathrm{H}), 3.08($ sexted, $J=7.2 \mathrm{~Hz}, 1 \mathrm{H})$, $2.56(\mathrm{~m}, 2 \mathrm{H}), 2.53(\mathrm{~m}, 2 \mathrm{H}), 2.39(\mathrm{~m}, 2 \mathrm{H}), 2.06(\mathrm{~s}, 3 \mathrm{H}), 1.76$ (m, 2H), $1.68(\mathrm{~m}, 2 \mathrm{H}), 1.36(\mathrm{dt}, J=13.8,3.6 \mathrm{~Hz}, 2 \mathrm{H}), 1.00$ (s, 3H), 0.99 (s, 3H), 0.96 (s, 3H); ${ }^{13} \mathrm{C}-\mathrm{NMR}(125.8 \mathrm{MHz}$, $\left.\mathrm{CDCl}_{3}\right) \delta_{\mathrm{C}}: 194.1(\mathrm{CH}), 170.8(\mathrm{C}), 154.0(\mathrm{C}), 145.8(\mathrm{C})$, $144.1(\mathrm{CH}), 140.4(\mathrm{C}), 138.2(\mathrm{C}), 119.7(\mathrm{CH}), 74.1(\mathrm{CH})$, $67.4\left(\mathrm{CH}_{2}\right), 49.4(\mathrm{C}), 48.3(\mathrm{C}), 38.4\left(\mathrm{CH}_{2}\right), 36.3\left(\mathrm{CH}_{2}\right), 33.6$ $\left(\mathrm{CH}_{2}\right), 32.1(\mathrm{CH}), 29.5\left(\mathrm{CH}_{2}\right), 29.2\left(\mathrm{CH}_{2}\right), 26.4\left(\mathrm{CH}_{3}\right), 23.9$ $\left(\mathrm{CH}_{3}\right), 20.9\left(\mathrm{CH}_{3}\right), 16.1\left(\mathrm{CH}_{3}\right)$.

The $50 \%$ ethyl acetate/hexane eluate was further subjected to silica gel chromatography with acetone/chloroform mixtures to give a $10 \%$ acetone/chloroform eluate. The eluate was purified by ODS column chromatography with $70 \%$ methanol/ water, followed by purification by HPLC with an ODS column to give sarcodonin Q (2-oxo-sarcodonin B, $14 \mathrm{mg}$ ) (Hirota et al, Abstract of Japan Society of Bioscience, Biotechnology and Biochemistry, National meeting 2004, Hiroshima, p282, 2004). Sarcodonin Q: $[\alpha]^{18}+793^{\circ}\left(c 0.35, \mathrm{CHCl}_{3}\right)$; EIMS $\mathrm{m} / \mathrm{z}$ (relative intensity): $314\left(\mathrm{M}^{+}, 96 \%\right), 296(50 \%), 285$ (100\%), 267 (48\%), 253 (63\%), 240 (56\%), 215 (37\%), 91 (37\%), $72(59 \%), 59(82 \%)$; HREIMS m/z 314.1869 [M] $^{+}$ (calculated for $\mathrm{C}_{20} \mathrm{H}_{26} \mathrm{O}_{3}, 314.1882$ ); IR (film) $v_{\max } \mathrm{cm}^{-1}$ : 3462, 2962, 2929, 2870, 1690, 1674, 1582; UV $\lambda_{\max } 319 \mathrm{~nm}$ ( $\left.1.1 \times 10^{4}\right)$; ${ }^{1} \mathrm{H}-\mathrm{NMR}\left(500.1 \mathrm{MHz}, \mathrm{CDCl}_{3}\right) \delta_{\mathrm{H}}: 9.51(\mathrm{~s}, 1 \mathrm{H})$, $6.89(\mathrm{dd}, J=8.0,2.4 \mathrm{~Hz}, 1 \mathrm{H}), 6.02(\mathrm{~d}, J=8.0 \mathrm{~Hz}, 1 \mathrm{H}), 3.79$ $(\mathrm{d}, J=5.7 \mathrm{~Hz}, 1 \mathrm{H}), 3.25(\mathrm{dd}, J=18.3,6.0 \mathrm{~Hz}, 1 \mathrm{H}), 2.73$ (hepted, $J=7.0 \mathrm{~Hz}, 1 \mathrm{H}$ ), 2.59 (br.d, $J=18.0 \mathrm{~Hz}, 1 \mathrm{H}$ ), 2.33 $(\mathrm{d}, J=18.7 \mathrm{~Hz}, 1 \mathrm{H}), 2.25(\mathrm{~d}, J=18.7 \mathrm{~Hz}, 1 \mathrm{H}), 2.61(\mathrm{~m}, 1 \mathrm{H})$, $1.93(\mathrm{dq}, J=13.3,2.3 \mathrm{~Hz}, 1 \mathrm{H}), 1.69(\mathrm{td}, J=13.8,4.5 \mathrm{~Hz}$, $1 \mathrm{H}), 1.26(\mathrm{~d}, J=7.1 \mathrm{~Hz}, 3 \mathrm{H}), 1.01(\mathrm{~s}, 3 \mathrm{H}), 1.16(\mathrm{~s}, 3 \mathrm{H}), 1.16$ $(\mathrm{d}, J=6.9 \mathrm{~Hz}, 3 \mathrm{H}) ;{ }^{13} \mathrm{C}-\mathrm{NMR}\left(125.8 \mathrm{MHz}, \mathrm{CDCl}_{3}\right) \delta_{\mathrm{C}}: 207.2$ (C), $193.7(\mathrm{CH}), 175.6(\mathrm{C}), 151.1(\mathrm{C}), 144.5(\mathrm{C}), 142.7(\mathrm{CH})$, $140.0(\mathrm{C}), 121.4(\mathrm{CH}), 73.3(\mathrm{CH}), 51.3\left(\mathrm{CH}_{2}\right), 49.0(\mathrm{C}), 42.1$ (C), $35.6\left(\mathrm{CH}_{2}\right), 31.4\left(\mathrm{CH}_{2}\right), 28.9\left(\mathrm{CH}_{2}\right), 26.4\left(\mathrm{CH}_{3}\right), 25.8$ $(\mathrm{CH}), 24.0\left(\mathrm{CH}_{3}\right), 21.4\left(\mathrm{CH}_{3}\right), 20.7\left(\mathrm{CH}_{3}\right)$.

The $50 \%$ ethyl acetate/hexane eluate was further purified by column chromatography on silica gel with acetone/chloroform mixtures to give $20 \%$ acetone/chloroform eluate, which was subjected to ODS column chromatography with methanol/ water mixtures to yield a methanol eluate $(100 \mathrm{mg})$. Finally HPLC with ODS column gave neosarcodonin H (16 mg). Neosarcodonin $\mathrm{H}$ : colorless resin; $[\alpha]^{18}{ }_{\mathrm{D}}-7.7^{\circ}$ (c 1.41, methanol); EI-MS $m / z$ (relative intensity): 424 [M+, 2\%], 406 $\left[\mathrm{M}^{+}-\mathrm{H}_{2} \mathrm{O}, 9 \%\right], 388\left[\mathrm{M}^{+}-2 \mathrm{H}_{2} \mathrm{O}, 15 \%\right], 241(80 \%), 189(73 \%)$, 105 (100\%); HREIMS m/z $406.2539\left[\mathrm{M}^{+}-\mathrm{H}_{2} \mathrm{O}\right]$ (calculated for $\mathrm{C}_{27} \mathrm{H}_{34} \mathrm{O}_{3}, 406.2532$ ); IR (film) $v_{\max } \mathrm{cm}^{-1}: 3420,2920,1705$, $1640,1270,705$; UV $\lambda_{\max }: 228 \mathrm{~nm}\left(\varepsilon 1.50 \times 10^{4}\right)$; ${ }^{1} \mathrm{H}-\mathrm{NMR}$ $\left(500.1 \mathrm{MHz}, \mathrm{CDCl}_{3}\right) \delta_{\mathrm{H}}: 8.05(\mathrm{~d}, J=7.4 \mathrm{~Hz}, 2 \mathrm{H}), 7.57(\mathrm{~d}$, $J=7.4 \mathrm{~Hz}, 1 \mathrm{H}), 7.45$ (t, $J=7.6 \mathrm{~Hz}, 2 \mathrm{H}), 6.25$ (br.d, $J=9.6 \mathrm{~Hz}$, $1 \mathrm{H}), 5.94(\mathrm{~d}, J=6.8 \mathrm{~Hz}, 1 \mathrm{H}), 4.25(\mathrm{~d}, J=13.8 \mathrm{~Hz}, 1 \mathrm{H}), 4.18$ $(\mathrm{d}, J=13.9 \mathrm{~Hz}, 1 \mathrm{H}), 4.00(\mathrm{~d}, J=6.7 \mathrm{~Hz}, 1 \mathrm{H}), 3.10(\mathrm{~d}, J=$ $11.8 \mathrm{~Hz}, 1 \mathrm{H}), 2.89$ (hepted, $J=6.7 \mathrm{~Hz}, 1 \mathrm{H}), 2.35(\mathrm{~m}, 1 \mathrm{H})$, $2.29(\mathrm{~m}, 2 \mathrm{H}), 2.21(\mathrm{~m}, 1 \mathrm{H}), 2.07(\mathrm{~m}, 1 \mathrm{H}), 1.47(\mathrm{~m}, 2 \mathrm{H}), 1.44$ $(\mathrm{m}, 2 \mathrm{H}), 1.02(\mathrm{~s}, 3 \mathrm{H}), 0.97(\mathrm{~d}, J=6.7 \mathrm{~Hz}, 3 \mathrm{H}), 0.93(\mathrm{~d}, J=$ $6.8 \mathrm{~Hz}, 3 \mathrm{H}), 0.85(\mathrm{~s}, 3 \mathrm{H}) ;{ }^{13} \mathrm{C}-\mathrm{NMR}\left(125.8 \mathrm{MHz} \mathrm{CDCl}_{3}\right) \delta_{\mathrm{C}}$ : $166.0(\mathrm{C}), 144.2(\mathrm{C}), 139.7(\mathrm{C}), 138.3(\mathrm{C}), 133.2(\mathrm{CH}), 130.2$ (C), $129.6(\mathrm{CH}), 128.5(\mathrm{CH}), 127.6(\mathrm{CH}), 76.2(\mathrm{CH}), 74.3$ $(\mathrm{CH}), 64.1\left(\mathrm{CH}_{2}\right), 49.4(\mathrm{C}), 42.1(\mathrm{C}), 40.0(\mathrm{CH}), 38.0\left(\mathrm{CH}_{2}\right)$, $36.9\left(\mathrm{CH}_{2}\right), 33.8\left(\mathrm{CH}_{2}\right), 33.1\left(\mathrm{CH}_{2}\right), 28.7\left(\mathrm{CH}_{2}\right), 26.9(\mathrm{CH})$, $24.4\left(\mathrm{CH}_{3}\right), 21.9\left(\mathrm{CH}_{3}\right), 21.8\left(\mathrm{CH}_{3}\right), 16.8\left(\mathrm{CH}_{3}\right)$.

The $60 \%$ and $70 \%$ ethyl acetate/hexane eluates were further purified by column chromatography on silica gel with acetone/chloroform mixtures followed by ODS column chromatography to give sarcodonin G (210 mg) (7).

The structures of the four cyathane diterpene compounds were elucidated as shown in Fig. 1 on the basis of spectral data. Each of the isolated cyathane diterpenes was dissolved in dimethyl sulfoxide (DMSO) (Wako, Osaka, Japan). Anticancer drugs used were as follows: 5-fluorouracil (5-FU) (F6627, Sigma, St. Louis, MO, USA) and cis-diammineplatinum (II) dichloride (cisplatin) (076K1697, Sigma). As a caspase inhibitor, Z-VAD-FMK (G7232, Promega Corp., Madison, WI, USA) was used. Unless specifically stated, other reagents were purchased from Wako Pure Chemical Industry (Osaka, Japan).

Cells and culture conditions. The following human cell lines were used: HeLa (a cervical cancer cell line) (13), HEC-1 (an endometrial adenocarcinoma cell line) (15), HOC-21 (an ovarian serous cystadenocarcinoma cell line) (15), U251SP (a glioma cell line) (14), MM-1CB (a melanoma cell line) (15) and HMV-1 (a melanoma cell line) (15). Cells were cultured in Eagle's minimal essential medium (EMEM), containing $10 \%$ (v/v) calf serum (Invitrogen, Carlsbad, CA, USA) and antibiotics (100 $\mu \mathrm{g} / \mathrm{ml}$ of streptomycin, Meiji Seika, Tokyo, Japan) and $100 \mathrm{U} / \mathrm{ml}$ of penicillin $\mathrm{G}$ (Meiji Seika), at $37^{\circ} \mathrm{C}$ in a humidified atmosphere containing $5 \% \mathrm{CO}_{2}$.

Measurement of cell viability. Cell viability was estimated by the MTT assay as previously described (16). Briefly, logarithmically proliferating cells were plated onto 96-well plates (Asahi Glass, Tokyo, Japan) $\left(1 \times 10^{4}\right.$ cells/well) with the medium containing the test compounds at the indicated doses, followed by culture for 2 days. After the culture, the activity of mitochondrial succinic dehydrogenase was measured by further incubation of the cells with $0.5 \mathrm{mg} / \mathrm{ml} \mathrm{3-(4,5-}$ dimethylthiazol-2-yl)-2,5-diphenyl tetrazolium bromide (MTT) (Sigma) for $4 \mathrm{~h}$, followed by measurement of absorbance at 


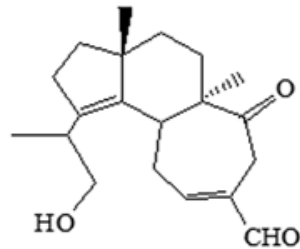

sarcodonin $\mathrm{G}(\mathrm{SG})$
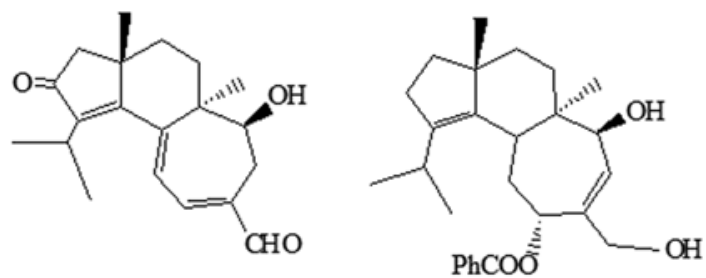

sarcodonin Q (SQ) neosarcodonin H (neoSH)

Figure 1. Chemical structures of 4 cyathane diterpenes.

$570 \mathrm{~nm}$ with a reference wavelength at $655 \mathrm{~nm}$. Cell survival was calculated from absorbance and presented as a percentage of the surviving cells.

Cell proliferation numbers per one dish were estimated principally according to the method described previously (14). Briefly, cells were seeded at $1 \times 10^{5}$ cells per $60-\mathrm{mm}$ dish (Corning, NY, USA), and 1 day later were replenished with medium containing the indicated agents. After the replenishment, cells were cultured during the indicated days until 7 days after the seeding. Changes of medium with and without agents were carried out every other day. Viable cells were determined by the Trypan-blue dye exclusion test and counted with a hemocytometer.

Measurement of cell-cycle phase distribution. Cell-cycle phase distributions were measured as described previously (16). Briefly, cells were cultured in 60-mm dishes with SG $(\leq 100 \mu \mathrm{M})$ for $24 \mathrm{~h}$, followed by trypsinization, washed three times with PBS and fixed in $70 \%$ cold ethanol. After fixation, cells were suspended in staining solution $(50 \mu \mathrm{g} / \mathrm{ml}$ of propidium iodide (PI), $4 \mathrm{mM}$ sodium citrate, $0.2 \mathrm{mg} / \mathrm{ml}$ RNase A, and $0.1 \%$ Triton $\mathrm{X}-100$ ) for $10 \mathrm{~min}$ on ice. $\mathrm{NaCl}$ was then added to the solution to a final concentration of $0.15 \mathrm{M}$. The stained cell samples were analyzed using a FACScan instrument (Becton-Dickinson, NJ, USA). Cells undergoing apoptosis were evaluated as a percentage of cells with a sub- $\mathrm{G}_{1}$ population. The fraction of sub- $\mathrm{G}_{1}$ population was calculated with computer software, CellQuest (BectonDickinson). Cell-cycle phase distribution measurements were repeated in three different cultures.

DNA fragmentation analysis. Apoptotic DNA fragments were detected as previously described (17). Briefly, SG $(\leq 100 \mu \mathrm{M})$ treated and mock-treated cells were cultured for $48 \mathrm{~h}$, and then lysed for $3 \mathrm{~h}$ at $37^{\circ} \mathrm{C}$ in a solution containing $50 \mathrm{mM}$
Tris- $\mathrm{HCl}(\mathrm{pH} 8.0), 2 \mathrm{mM}$ EDTA, $1 \%$ SDS and $100 \mu \mathrm{g} / \mathrm{ml}$ proteinase K. Following the addition of one-tenth volume of $3 \mathrm{M}$ sodium acetate, nucleotides were extracted with phenol/ chloroform and then with chloroform alone. High-molecular weight DNA was precipitated by addition of 2-propanol by seven-tenth volume, followed by centrifugation at 15,000 rpm for $5 \mathrm{sec}$ at room temperature. Low-molecular weight DNA was recovered from the supernatant by centrifugation after incubation overnight at $-20^{\circ} \mathrm{C}$, re-suspended in $10 \mathrm{mM}$ Tris- $\mathrm{HCl}$ (pH 8.0), $1 \mathrm{mM}$ EDTA and $50 \mu \mathrm{g} / \mathrm{ml}$ of DNase-free RNase A and then incubated for $3 \mathrm{~h}$ at $37^{\circ} \mathrm{C}$. Samples were applied to $1.5 \%$ agarose gel containing $0.5 \mu \mathrm{g} / \mathrm{ml}$ ethidium bromide, and electrophoresed in $90 \mathrm{mM}$ Tris-borate ( $\mathrm{pH} 8.0$ ) and $2 \mathrm{mM}$ EDTA at $100 \mathrm{~V}$ for $3 \mathrm{~h}$. DNA ladders were photographed under UV illumination.

Immunoblot analysis. Immunoblot analysis was carried out as described previously (18). After SG treatment for $24 \mathrm{~h}$, cells were solubilized in $1 X$ SDS sampling buffer. The whole cell lysates were separated by electrophoresis on $12 \%(\mathrm{w} / \mathrm{v})$ SDS-PAGE. Active forms of caspase- 3 and caspase- 9 proteins were detected using rabbit anti-cleaved caspase- 3 antibody (2305-PC-020, Trevigen, MD, USA) (1:800 dilution) and mouse anti-human caspase-9 antibody (MAB8301, R\&D, Minneapolis, MN, USA) (1:1000 dilution), respectively. The latter antibody detects non-cleaved and cleaved caspase- 9 . $\mathrm{Bax}$ and $\mathrm{Bcl}-2$ proteins were detected using anti-mouse Bax monoclonal antibody (SC-7480, Santa Cruz Biotechnology, USA) (1:300 dilution) and anti-mouse Bcl-2 monoclonal antibody (Santa Cruz Biotechnology) (SC-7382, 1:300 dilution), respectively. The antigen-antibody complexes were detected by anti-rabbit IgG (NA934V, GE, Healthcare, UK) and anti-mouse IgG (NA931V, Amersham Biosciences, Buckinghamshire, UK), followed by visualization using the ECL system (GE). Amounts of actin were also analyzed by mouse anti-actin antibody (NA931V, Illkirch, Cedex, France) (1:20000 dilution) as the loading control. The intensities of the protein signals were quantified using Multi Gauge Ver2.2 image analyzing software (Fuji Foto Film, Tokyo, Japan) and expressed as a relative value to that of actin.

Other conditions. Values were expressed as means of those obtained from more than two independent experiments, unless specifically stated otherwise. Mock treatment was performed under the solvent conditions containing $0.1 \%$ DMSO. Statistical analysis was performed using the Student's t-test with StatView software (Version 4.5; Abacus Concepts, Berkeley, CA, USA), as previously described (18).

\section{Results}

Inhibition of viability of HeLa cells by SG. The cytotoxic potential of 4 isolated diterpenes (Fig. 1) was tested by the MTT assay after culture of HeLa cells in the presence of the chemical compounds for two days. Both the SE and SQ treatment resulted in only a slight decrease in cell viability among the doses tested $(\leq 100 \mu \mathrm{M})$ (Fig. 2). NeoSH treatment resulted in the same extent of cell viability inhibition as that of the control 5-FU (Fig. 2). However, SG treatment showed dose-dependent inhibition to a greater extent than 5-FU, 


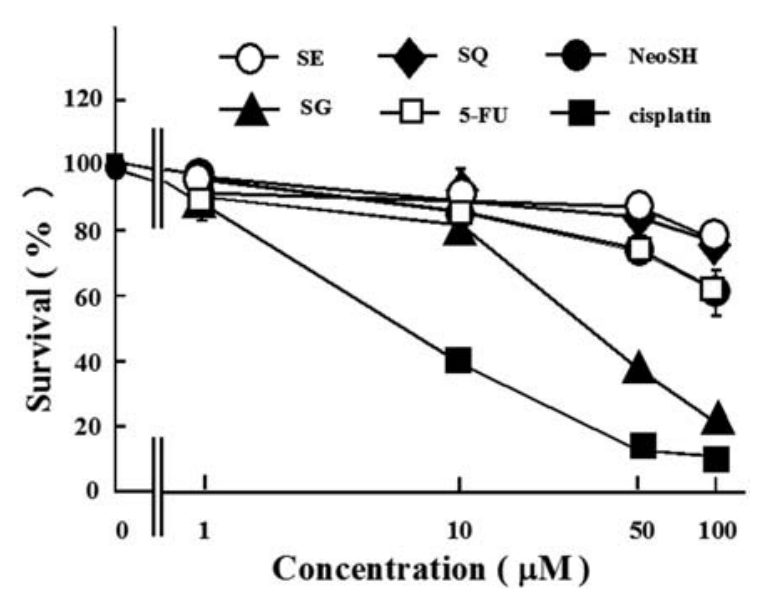

Figure 2. Comparison of cell viability in HeLa cells treated with diterpenes, 5-FU and cisplatin. HeLa cells were treated with the indicated agents for 2 days, followed by estimation of cell viability by the MTT assay, as described in Materials and methods. Data are presented as means \pm SD of three independent experiments.

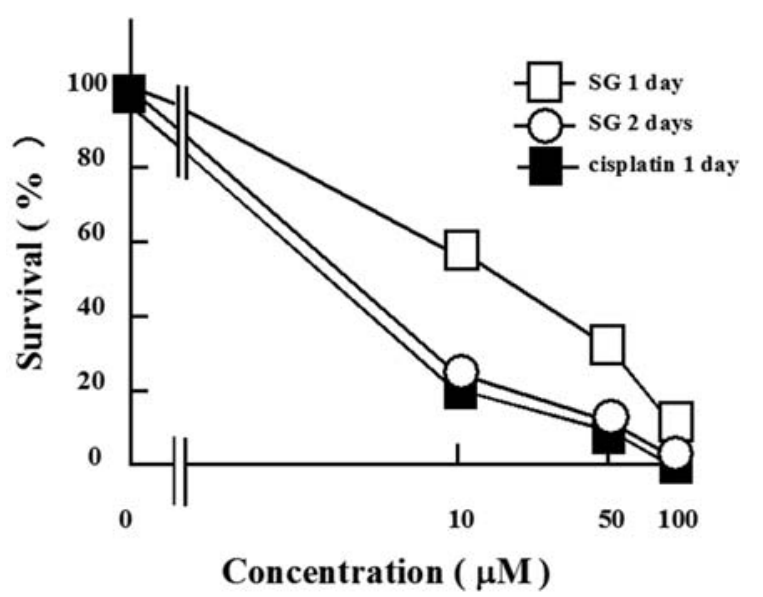

Figure 3. Comparison of sensitivity to SG and cisplatin in HeLa cells. HeLa cells were treated with SG $(\square)$ and cisplatin $(\square)$ for $24 \mathrm{~h}$ and with SG ( $\square$ ) for $48 \mathrm{~h}$. After 4 days of culture, Trypan blue-eliminating cells were counted as survived cells, as described in Materials and methods. Data are presented as means $\pm \mathrm{SD}$.

although the inhibition was not so strong as that of cisplatin (Fig. 2). The $\mathrm{IC}_{50}$, the concentration to inhibit the proliferation of HeLa cells by $50 \%$, of SG, 5-FU and cisplatin was $18 \mu \mathrm{M}$, $>100 \mu \mathrm{M}$ and $3.0 \mu \mathrm{M}$, respectively.

The anti-proliferative activity of SG was also evaluated in comparison with that of cisplatin by a cell proliferation test. After 1-day exposure to SG at a concentration in excess of $10 \mu \mathrm{M}$, the proliferation of HeLa cells was inhibited; the extent of the inhibition was less than that after 1-day exposure to cisplatin at the same concentration (Fig. 3). However, when HeLa cells were exposed for 2 days to SG at a concentration in excess of $10 \mu \mathrm{M}$, the proliferation was inhibited to the same extent as that after 1-day exposure to cisplatin at the same concentration (Fig. 3).

Apoptotic events in SG-treated HeLa cells. The cell cycle distribution in HeLa cells was examined by flow cytometric analysis after PI staining. A distinct increase in the population

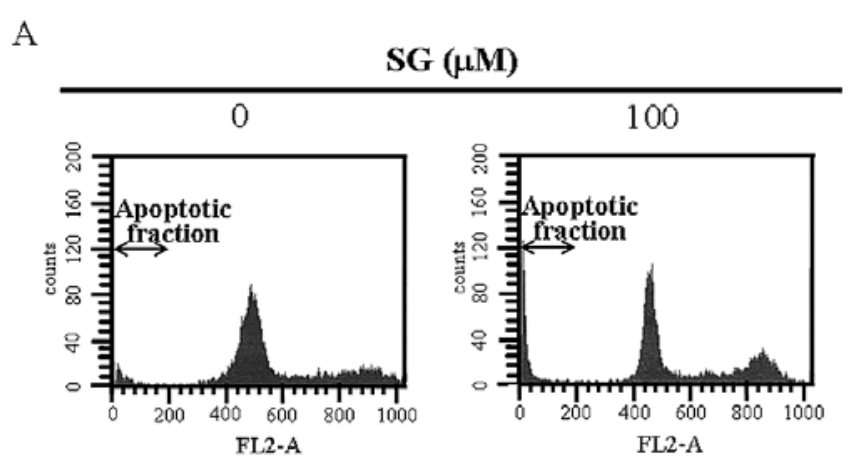

$\mathrm{B}$

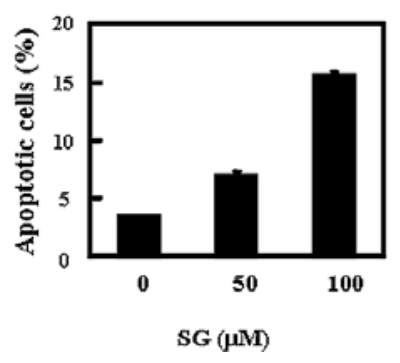

Figure 4. Flow cytometric analysis of SG-treated HeLa cells. (A) Flow cytometric profiles for DNA contents of HeLa cells after treatment with SG. HeLa cells were treated with SG for $24 \mathrm{~h}$ and subjected to analysis. The profiles are displayed as fluorescence intensities of PI versus relative cell numbers. Apoptotic fraction is indicated. (B) Graph shows the fraction of apoptotic cell population. HeLa cells were treated with $0,50,100 \mu \mathrm{M}$ of SG for $24 \mathrm{~h}$. At least $1 \times 10^{4}$ cells were counted for each condition. Data are presented as means \pm SD of three independent experiments.

of cells in the sub- $\mathrm{G}_{1}$ phase (apoptotic fraction) was observed in the cells treated with $100 \mu \mathrm{M} \mathrm{SG}$ for 1 day (Fig. 4A). The increase was dose-dependent $\leq 100 \mu \mathrm{M} \mathrm{SG}$ (Fig. 4B). These results suggested the induction of apoptosis in SG-treated HeLa cells. To confirm that SG causes apoptosis, the fragmentation status of genomic DNA was examined in HeLa cells treated with the compound. Short fragments of DNA were observed in cells treated with 50 and $100 \mu \mathrm{M}$ of SG (Fig. 5A), although the distinct fragmentation was observed after treatment with cisplatin at concentrations higher than $25 \mu \mathrm{M}$ (Fig. 5B).

Activation of caspases in SG-treated HeLa cells. To elucidate the mechanisms of SG treatment-induced apoptosis in HeLa cells, we assessed the possible involvement of caspases, by detecting the active cleaved forms of caspase-3 and -9 . Amounts of both active forms increased by a small extent after 1-day treatment with $50 \mu \mathrm{M} \mathrm{SG}$ (Fig. 6), but a $100 \mu \mathrm{M}$ SG treatment resulted in more than 3-fold increase compared to the mock treatment (Fig. 6), similar to that with $50 \mu \mathrm{M}$ cisplatin (Fig. 6A), illustrating the functional relevance of caspase activation during SG treatment-induced apoptosis.

Suppression of SG treatment-induced cell death by Z-VADFMK in HeLa cells. To evaluate caspase activation in SGtreated HeLa cells, the effect of a general caspase inhibitor, Z-VAD-FMK, on SG treatment-induced cell death was examined by combined treatment of the inhibitor with SG. The Z-VAD-FMK combination resulted in a slight increase of survival at $10 \mu \mathrm{M} \mathrm{SG}$ and a more pronounced increase at concentrations in excess of $50 \mu \mathrm{M} \mathrm{SG}$ (Fig. 7). These results indicated that caspase activation was causally related to SG 
A

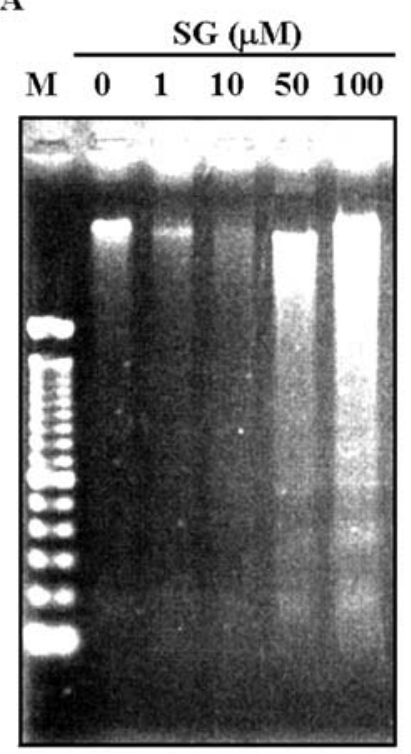

B

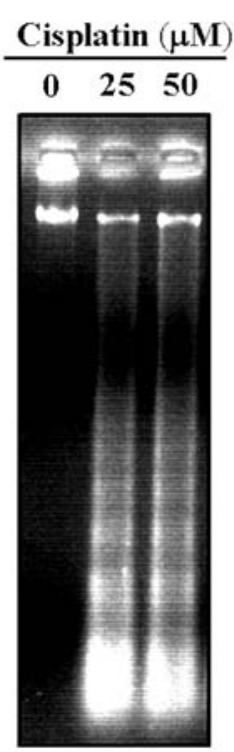

Figure 5. Comparison of SG- and cisplatin-induced DNA fragmentation in HeLa cells. Cells were treated with vehicle (DMSO) and indicated concentrations of SG (A) and cisplatin (B) for $48 \mathrm{~h}$, and then the total DNA preparation and detection of the DNA fragment were performed as described in Materials and methods. $M$ represents molecular markers.

A

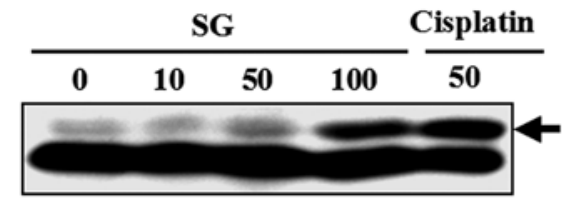

Caspase-9

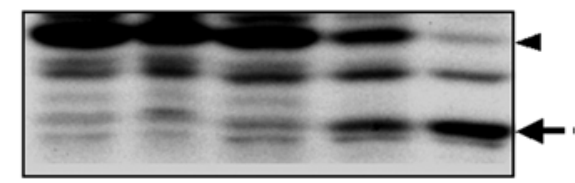

Actin



B

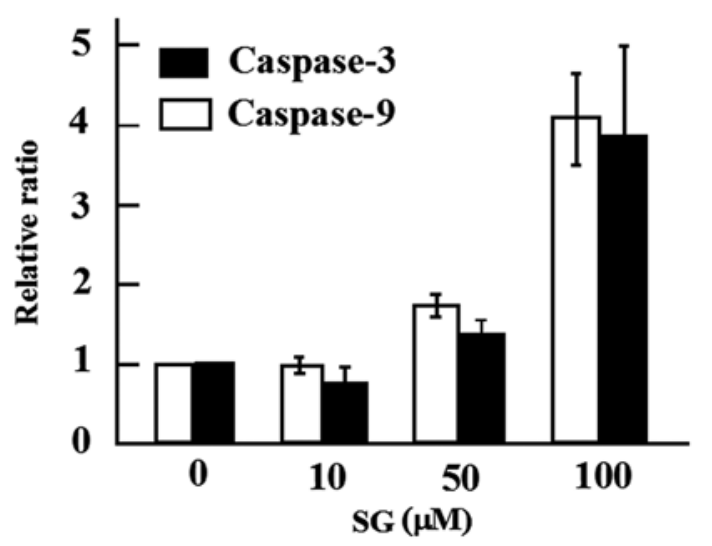

Figure 6. Expression of caspase- 3 and caspase-9 protein in HeLa cells treated with and without SG. Cells were treated with vehicle (DMSO) and indicated concentrations of SG and cisplatin for $24 \mathrm{~h}$, and then the expression levels of caspase-3, caspase- 9 and actin protein were analyzed by Western blotting in Materials and methods (A). Bands representing the cleaved forms of caspase- 3 and caspase- 9 are shown by an arrow and the band of the noncleaved form of caspase- 9 is shown by an arrowhead. Protein levels of caspase-3 and caspase- 9 are presented as relative ratio to those of the cells without SG treatment, after normalization with actin levels (B). Data are presented as means $\pm \mathrm{SD}$.

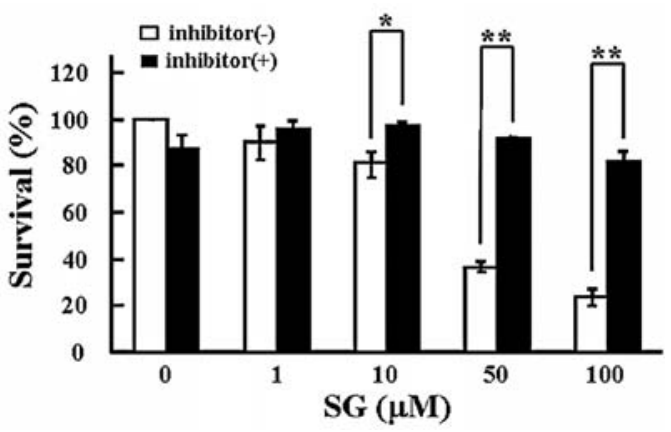

Figure 7. Comparison of cell viability of HeLa cells cultured in the presence or absence of Z-VAD-FMK during SG treatment. Cells were treated with SG in the presence or absence of Z-VAD-FMK for 2 days, and cell viability was examined by the MTT assay as described in Materials and methods. Data are presented as means $\pm \mathrm{SD} .{ }^{*} \mathrm{P}<0.005,{ }^{* *} \mathrm{P}<0.001$.

$\mathbf{A}$

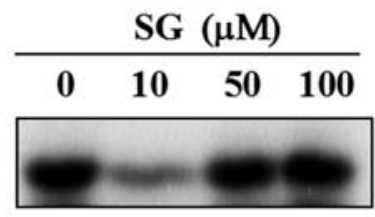

Bax

Bcl-2

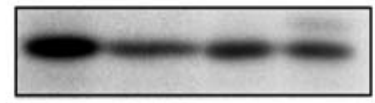

Actin

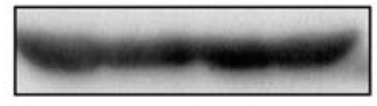

B

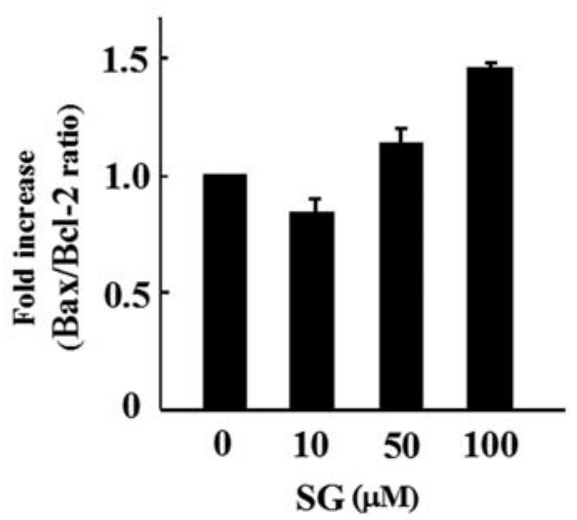

Figure 8. Expression of Bax and Bcl-2 protein in HeLa cells treated with and without SG. Cells were treated with vehicle (DMSO) and indicated concentrations of SG for $24 \mathrm{~h}$, and then the expression levels of Bax, Bcl-2 and actin protein were analyzed by Western blotting as described in Materials and methods (A). Protein levels of Bax and Bcl-2 were normalized with actin levels and are presented as the ratio of Bax to Bcl-2 (B). Data are presented as means $\pm \mathrm{SD}$.

treatment-induced cell death, and that this finding is further evidence that SG treatment induces apoptosis in HeLa cells.

Increased ratios of Bax/Bcl-2 in SG-treated HeLa cells. To further investigate the molecules involved in SG treatmentinduced apoptosis, we estimated amounts of Bax and Bcl-2 proteins, proteins involved in caspase induction, in HeLa cells treated with and without SG for 1 day. Western blot analysis showed that expression of the Bcl-2 protein decreased after SG treatment (50-100 $\mu \mathrm{M})$ (Fig. 8A) and Bax/Bcl-2 

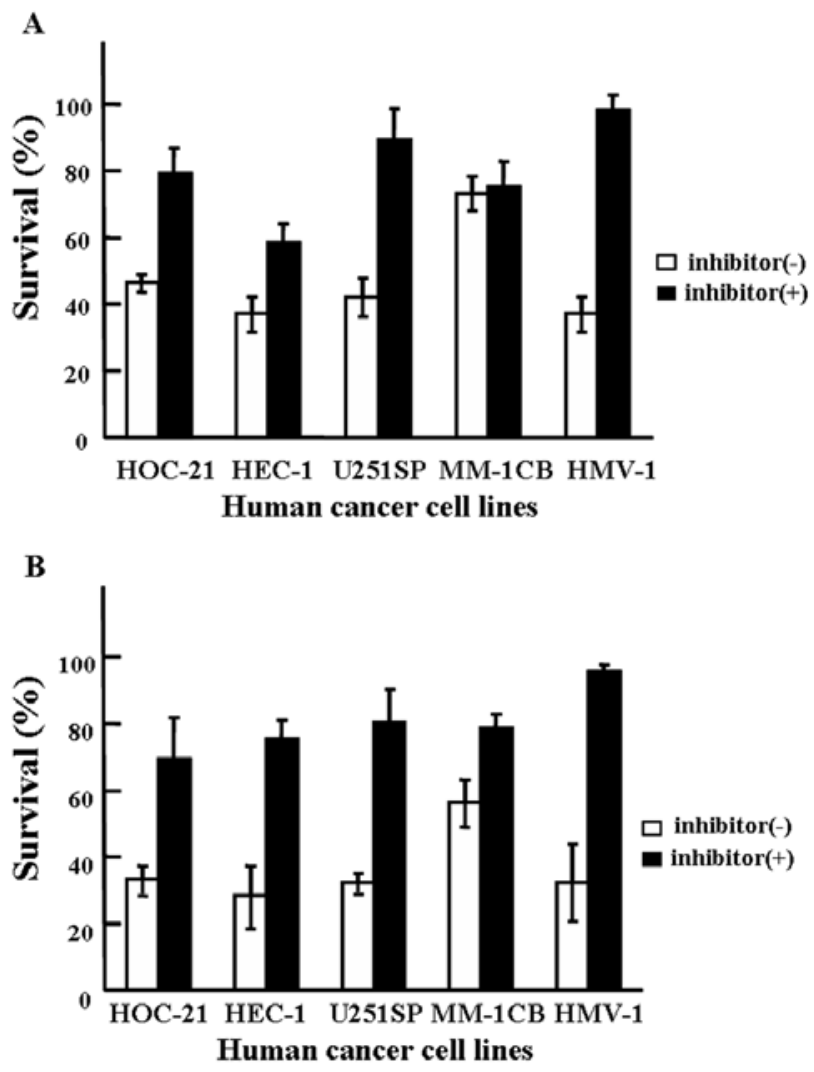

Figure 9. Comparison of cell viability of human cancer cell lines cultured in the presence or absence of Z-VAD-FMK during SG treatment. Cells were treated with $50 \mu \mathrm{M} \mathrm{SG}$ (A) and $100 \mu \mathrm{M} \mathrm{SG}$ (B) in the presence or absence of Z-VAD-FMK for 2 days, and cell viability was examined by the MTT assay as described in Materials and methods. Data are presented as means $\pm \mathrm{SD}$.

protein ratios increased (Fig. 8B), although the ratios decreased slightly after treatment with $10 \mu \mathrm{M} \mathrm{SG}$. Thus, the Bax/Bcl-2 ratio correlated with apoptosis induced by higher than $50 \mu \mathrm{M}$ SG in HeLa cells.

$S G$ treatment-induced cell death in 5 other cancer cell lines and its suppression by Z-VAD-FMK. As well as HeLa cells, 5 other human cancer cell lines (HOC-21, HEC-1, U251-SP, MM-1CB and HMV-1) were tested for their susceptibility to SG. Distinct inhibition of cell survival was observed after both $50 \mu \mathrm{M}$ (Fig. 9A) and $100 \mu \mathrm{M}$ (Fig. 9B) SG treatments in all cell lines, including HeLa cells (Fig. 7), although MM-1CB cells were less susceptible to SG than the other 5 cell lines (Fig. 9). Additionally, SG treatment-induced cell death was suppressed by Z-VAD-FMK in these 5 cell lines (Fig. 9), as already observed in HeLa cells (Fig. 7). Particularly, U251SP and HMV-1 cells treated with Z-VAD-FMK showed 2-fold higher survival levels than those treated with SG alone (Fig. 9), suggesting sufficient recovery of survival by Z-VAD-FMK. The results indicate that $S G$ also induced apoptosis in these human cancer cell lines.

\section{Discussion}

Among 4 chemicals purified from Sarcodon scabrosus, SG seemed to exhibit the greatest inhibition of HeLa cell viability, estimated by the MTT assay (Fig. 2) and cell proliferation (Fig. 3) analyses. The sensitivity of HeLa cells to SG was higher than that to 5-FU, but lower than that to cisplatin (Figs. 2 and 3).

Some chemotherapeutic anticancer agents including 5-FU and cisplatin are known to induce apoptosis $(19,20)$, as shown here by DNA fragmentation in cisplatin-treated HeLa cells (Fig. 5). In the present study SG (at concentrations in excess of $50 \mu \mathrm{M}$ ) also induced apoptotic events in HeLa cells; increased population in apoptotic sub- $\mathrm{G}_{1}$ fraction (Fig. 4) and DNA fragmentation (Fig. 5). The mechanisms underlying the SG-induced apoptosis in HeLa cells were revealed by increased amounts of the active forms of caspases-3 and/or -9 (Fig. 6). Activated caspase-9 is thought to cleave and to activate the other effector caspases such as caspase-3, leading to apoptotic events (21). Thus, activation of caspase-3 and/ or -9 may be involved in SG-induced apoptosis. The causal relationship of SG-induced apoptosis and caspase activation was also confirmed by suppression of apoptosis in HeLa cells treated with a caspase inhibitor, Z-VAD-FMK, and SG (Fig. 7).

Our data also demonstrated modulation of Bax and Bcl-2 in SG-treated HeLa cells (Fig. 8A). Bax and Bcl-2 are proapoptotic and anti-apoptotic proteins, respectively (22). The relative expression ratio of Bax versus Bcl-2 was reported to be correlated with 5-FU sensitivity in various cancer cell lines (23). On the other hand, one of the intrinsic pathways of caspase activation is suggested to be up-regulation of the ratio of protein amounts of Bax versus Bcl-2 $(23,24)$. In fact, this $\mathrm{Bax} / \mathrm{Bcl}-2$ ratio increased in SG (at concentrations in excess of $50 \mu \mathrm{M}$ )-treated HeLa cells (Fig. 8B). Therefore, it is possible that SG treatment (at concentrations in excess of $50 \mu \mathrm{M}$ ) induces caspase-mediated apoptosis in HeLa cells via modulation of Bax and Bcl-2.

The viability of 5 other cancer cell lines was decreased by SG treatment and the suppression of the SG effect was observed in combination with Z-VAD-FMK treatment (Fig. 9). Thus, it seems likely that SG has a lethal effect on various cancer cells, at least those tested here, possibly via caspase activation.

SG treatment results in an anti-inflammatory effect on TPA-induced inflammation in mice $(4,6)$. This effect was not affected by the combination treatment with Z-VAD-FMK (data not shown). Thus, Z-VAD-FM-sensitive caspases are not involved in the anti-inflammatory action of SG. There is growing interest in the elucidation of the biological functions of terpenes that are used as anticancer and anti-inflammatory agents (25-27). Diterpenes, such as SG, may be useful starting points for the development of anticancer and anti-inflammatory chemotherapy through pursuing a thorough investigation of the molecular mechanisms underlying diterpene-induced apoptosis.

\section{Acknowledgements}

The work described in this report was financially supported by the FRND of China (No: 2003AA2Z3527) and the Scientific Research Foundation for the Returned Overseas Chinese Scholars from Hebei Province and State Education Ministry of P.R. China. This work was also supported in part by grants-in-aid from the following organizations: the Goho 
Life Science International Foundation, the Smoking Research Foundation, the Tokyu Foundation for a Better Environment, and the Japan Society for the Promotion of Science. We also thank Dr Toshikazu Suzuki and Jun Lu for their valuable assistance.

\section{References}

1. Fuchs DA and Johnson RK: Cytologic evidence that taxol, an antineoplastic agent from Taxus brevifolia, acts as a mitotic spindle poison. Cancer Treat Rep 62: 1219-1222, 1978.

2. McGuire WP, Rowinsky EK, Rosenshein NB, Grumbine FC, Ettinger DS, Armstrong DK and Donehower RC: Taxol: a unique antineoplastic agent with significant activity in advanced ovarian epithelial neoplasms. Ann Int Med 111: 273-279, 1989.

3. Shi Q-W, Dong M, Huo C-H, Su X-H, Li C-F, Zhang X-P, Wang Y-F and Kiyota H: New 14-hydroxy-taxane and $2 \alpha, 20-$ epoxy-11 $(15 \rightarrow 1)$ abeotaxane from the needles of taxus canadensis. Biosci Biotechno Biochem 71: 1777-1780, 2007.

4. Hirota M, Sawamura R and Iriye R: Anti-inflammatory compounds from Callistemon rigidus. In: Progress in Drug Development from Medicinal Plants. Proceeding of UNESCO Regional Symposium on Drug Development from Medicinal Plants, Hangzhou, China, pp222-224, 1996.

5. Lee D-F, Kuo H-P, Chen C-T, Has J-M, Chou C-K, Wei T-H, Sun H-L, Li L-Y, Ping B, Huang W-C, He X-H, Hung J-Y, Lai C-C, Ding Q-Q, Su J-L, Yang J-Y, Sahin AA, Hortobagyi GN, Tsai F-J, Tsai C-H and Hang M-C: IKKß suppression of TSC1 links inflammation and tumor angiogenesis via the mTOR pathway. Cell 130: 440-455, 2007.

6. Hirota M, Morimura K and Shibata H: Anti-inflammatory compounds from the bitter mushroom, Sarcodon scabrosus. Biosci Biotechnol Biochem 66: 179-184, 2002.

7. Shibata H, Tokunaga T, Karaswa D, Hirota A, Nakayama M, Nozaki $\mathrm{H}$ and Tada $\mathrm{T}$ : Isolation and characterization of new bitter diterpenoids from the fungus Sarcodon scabrosus. Agric Biol Chem 53: 3373-3375, 1989.

8. Piers E, Gilbert M and Cook K-L: Total synthesis of the cyathane diterpenoid $( \pm)$-sarcodonin G. Org Lett 2: 1407-1410, 2000.

9. Yu Z-Y, Liang Y-G, Xiao H, Shan Y-J, Dong B, Huang R, Fu Y-L, Zhao Z-H, Liu Z-Y, Zhao Q-S, Wang S-Q, Chen J-P, Mao B-Z and Cong Y-W: Melissoidesin G, a diterpenoid purified from isodon melissoides, induces leukemic-cell apoptosis through induction of redox imbalance and exhibits synergy with other anticancer agents. Int J Cancer 121: 2084-2094, 2007.

10. Hickman JA: Apoptosis induced by anticancer drugs. Cancer Metastasis Rev 11: 121-139, 1992.

11. Dong M, Wang G, Guo W-Z, Sun Z, Hirota M and Cong B: Anti-tumor activity and mechanism of the compound from Sarcodn scabrosus karst. Nat Prod Res Dev 19: 88-91, 2007.
12. Kamo T, Imura Y, Hagio T, Makabe H, Shibata H and Hirota M: Anti-inflammatory cyathane diterpenoids from Sarcodon scabrosus. Biosci Biotechnol Biochem 68: 1362-1365, 2004.

13. Suzuki N and Fuse A: A UV-sensitive human clonal cell line, $\mathrm{RSa}$, which have low repair activity. Mutat Res 84: 133-145, 1981.

14. Suzuki N, Oiwa Y, Sugana I, Inaba N, Sekiya S, Fukazawa I, Yoshida J, Takakubo Y, Isogai E and Saito-Ebihara M: Dipyridamole enhances an anti-proloferative effect of interferon in various types of human tumor cells. Int J Cancer 51: 627-633, 1992.

15. Kojima T, Suzuki N, Sugano I and Hayata I: Enhancement of an anti-tumor effect of interferon by dipyridamole in established human malignant melanoma cell lines. Int J Cancer 46: 853-857, 1990.

16. Wano C, Lita K, Takahashi S, Sugaya S, Hino M, Hosoya H and Suzuki N: Protective role of HSP27 against UVC-induced cell death in human cells. Exp Cell Res 298: 584-592, 2004.

17. Wu Y, Kita K and Suzuki N: Involvement of human heat shock protein $90 \alpha$ in nicotine-induced apoptosis. Int J Cancer 100: 37-42, 2002.

18. Zhai L, Kita K, Wano C, Wu Y, Sugaya S and Suzuki N: Decreased cell survival and DNA repair capacity after UVC irradiation in association with down-regulation of GRP78/BiP in human RSa cells. Exp Cell Res 305: 244-252, 2005.

19. Lowe SW, Ruley HE, Jacks T and Housman DE: P53-dependent apoptosis modulates the cytotoxicity of anticancer agents. Cell 74: 957-967, 1993

20. Jakubowicz-Gil J, Rzymowska J, Paduch R and Gawron A: The effect of quercetin on pro-apoptotic activity of cisplatin in HeLa cells. Biochem Pharmacol 69: 1343-1350, 2005.

21. Schuler M and Green DR: Mechanisms of P53-dependent apoptosis. Biochem Soc Trans 29: 684-688, 2001.

22. Green DR and Kroemer G: The pathophysiology of mitochondrial cell death. Science 305: 626-629, 2004.

23. Mirjolet JF, Barberi MH, Didelot C, Peyrat JP, Abecassis J, Millon R and Merlin JL: Bcl-2/Bax protein ratio predicts 5fluorouracil sensitivity independently of p53 status. Br J Cancer 83: 1380-1386, 2000.

24. Murakami Y, Yokata EA, Sonoda Y, Ohta S and Kasahara T: Suppression of endoplasmic reticulum stress-induced caspase activation and cell death by the overexpression of $\mathrm{Bcl}-\mathrm{x}_{\mathrm{L}}$ or $\mathrm{Bcl}-2$. J Biochem 141: 401-410, 2007.

25. Ikeda Y, Murakami A and Ohigashi H: Ursolic acid: an anti- and pro-inflammatory triterpenoid (review). Mol Nutr Food Res 52: 26-42, 2008.

26. Wagner $\mathrm{KH}$ and Elmadfa I: Biological relevance of terpenoids. Overview focusing on mono-, di- and tetraterpenes. Ann Nutr Metab 7: 95-106, 2003.

27. Novotny L, Vachálková A and Biggs D: Ursolic acid: an antitumorigenic and chemopreventive activity (review). Neoplasma 48: 241-246, 2001. 